$\underline{\text { Review Article }}$

\title{
INSIGHTS INTO FORMULATION TECHNOLOGIES AND NOVEL STRATEGIES FOR THE DESIGN OF ORALLY DISINTEGRATING DOSAGE FORMS: A COMPREHENSIVE INDUSTRIAL REVIEW
}

\author{
AHMED M. AGIBAa*, AHMED B. ELDINb \\ aFormulation Department, Research and Development Directorate, SIGMA Pharmaceutical Industries, Egypt, bMethodology Department, \\ Research and Development Directorate, SIGMA Pharmaceutical Industries, Egypt \\ Email: ahmed.agiba@gmail.com
}

Received: 09 Jul 2019, Revised and Accepted: 10 Aug 2019

\begin{abstract}
Among the various routes of administration, the oral route remains the most convenient and commonly employed route for drug delivery. The oral conventional drug delivery systems have some drawbacks, such as possibility of gastrointestinal destruction of labile molecules, low absorption of macromolecules, slow onset of action, and unavoidable fluctuation in the concentration of drugs which can either lead to under-or over medication with concomitant adverse effects, especially for drugs with small therapeutic index. Therefore, it became essential to design novel oral drug delivery systems to achieve quick dissolution, absorption, rapid onset of action and reduction of drug dose. Among those novel drug delivery systems are oral disintegrating tablets (ODTs). The purpose of this review article is to report the recent advances in ODT systems with emphasis on their preparations, characterizations and applications. Also, it highlights future prospects and possible challenges in the development of an ideal ODT system.
\end{abstract}

Keywords: Oral disintegrating tablets, Preparations, Characterizations, Applications, Future prospects, Challenges

(C) 2019 The Authors. Published by Innovare Academic Sciences Pvt Ltd. This is an open access article under the CC BY license (http://creativecommons.org/licenses/by/4.0/] DOI: http://dx.doi.org/10.22159/ijpps.2019v119.34828

\section{INTRODUCTION}

The oral mucosal cavity is a very attractive and feasible site for local and systemic drug delivery, since the mucosal membranes, upon which drug delivery systems are placed, are readily accessible by the patients [1]. The oral mucosal drug delivery exhibits many advantages over other routs of drug administration, which include increased accessibility by the patients as the dosage form can be accurately placed on the desired oral cavity membrane location and can be easily removed in order to terminate delivery if signs of adverse reactions are observed during treatment which increases patient acceptability [1-3]. Moreover, the oral mucosa is a wellvascularised tissue directly draining into the jugular vein [4], hence, allowing direct delivery into the systemic circulation and avoidance of first-pass hepatic degradation. Oral mucosal delivery also avoids the gastrointestinal tract (GIT) environment preventing possible drug hydrolysis in the GIT, in addition to avoiding enzymatic barriers; i.e. low gastric $\mathrm{pH}$ and protease enzymes. However, the oral mucosal drug delivery represents a challenging area because of the inherent functions of the oral cavity as swallowing, chewing, and speaking [5]. Furthermore, saliva is constantly secreted into the buccal cavity from both major and minor salivary glands, causing severe dilution of the drug or excessively fast erosion of dosage forms. Furthermore, salivation leads to swallowing which removes the drug from the targeted site of absorption. Moreover, the oral mucosa has a smaller absorptive surface area which is approximately $214 \mathrm{~cm}^{2}$ [6] compared to the gastrointestinal mucosa $\left(350.000 \mathrm{~cm}^{2}\right)$. Despite the aforementioned limitations, oral mucosal delivery remains a viable option for drug delivery [3].

There are two major routes of drug absorption via oral mucosa; the transcellular (where drugs permeate directly through the cells) and paracellular (where drugs permeate by passive diffusion through the spaces between the cells) routes. The drug absorption process by passive diffusion is best expressed by Fick's first law [7], which states that drug molecules diffuse from a region of higher to lower concentration until equilibrium is achieved.

$$
\begin{gathered}
P=\frac{D . K p}{h} \text { (Eq. 1) } \\
A=P . C . S . t=\frac{D_{n} K p}{h} x \text { C.S.t }
\end{gathered}
$$

where $(\mathrm{P})$ is the permeability coefficient, $(\mathrm{A})$ is the amount of drug absorbed via oral mucosa, (D) is the diffusion coefficient of the drug, $\left(K_{p}\right)$ is the partition coefficient of the drug in between the oral mucosa and the specific medium used to deliver the drug, (h) is the thickness of the oral mucosa, (C) is the free drug concentration in the medium used to deliver the drug, (S) is the surface area of the oral mucosa, and $(\mathrm{t})$ is the duration or time of drug interacting the oral mucosa.

There must be a balance between partition coefficient and drug's solubility for a suitable oral mucosal delivery. In general, the permeability coefficient of lipophilic drugs is higher than hydrophilic drugs, and vice versa for solubility (i.e. the aqueous solubility of lipophilic drugs are usually lower than the hydrophilic drugs). Thus, the amount of drug absorbed via oral mucosa may be low for high lipophilic drugs. As a result, permeation enhancers are subsequently used to enhance drug absorption and permeation [7].

Understanding the physicochemical and solid-state properties of a drug substance is essential to obtain a rational formulation process. The desirable physicochemical and solid-state properties for drug delivery through oral mucosa are shown in table 1 [3]. Two factors mainly affect the effectiveness of oral drug delivery systems; the retention time of the drug delivery system in contact with the oral mucosa and its permeation rate.

\section{The need for development of oral disintegrating tablets}

Conventional oral dosage forms like tablets and capsules pose a great swallowing problem for paediatrics and geriatrics. Approximately $35 \%$ of the general population suffers from dysphasia [8]. Oral disintegrating tablets (ODTs) are tablets which are placed in the mouth and then get dispersed in saliva without the need of water [9-11]. ODTs are considered the dosage form of choice for psychiatric patients, patients requiring fast intervention as well as patients suffering from nausea, vomiting and motion sickness [12], since the ODT system presents a patient friendly dosage form which ensures patient compliance and adherence to treatment.

ODTs combine the advantages of solid and liquid dosage forms. Like conventional tablets, ODTs present accurate drug dosing, ease of both manufacturing and packaging, good chemical stability, as well as ease of handling by patients [13]. They also exhibit the smooth mouth feel and avoidance of swallowing problems encountered with 
liquid dosage forms. Additionally, ODTs provide rapid onset of action and improvement of the bioavailability of poorly absorbed drugs [14]. An ideal ODT exhibits the following characteristics [15]: (1) requires no water for oral administration, (2) dissolves, disperses or even disintegrates in the mouth in a matter of seconds, (3) has a pleasant mouth feel, (4) has good taste-masking potential,
(5) has sufficient hardness and acceptable friability limit, (6) leaves minimal or no residue in mouth after oral administration, (7) exhibits low sensitivity to environmental conditions, (8) is manufactured using conventional manufacturing methods, and (9) utilizes cost effective production method. Table 2 shows the suitability of drug candidates for ODTs [15].

Table 1: The desirable physicochemical and solid-state properties of a drug delivery through oral mucosa [3]

\begin{tabular}{ll}
\hline Property & Normal range \\
\hline Aqueous solubility & $>1 \mathrm{mg} / \mathrm{ml}$ \\
Lipophilicity & $10<0$ oil: water partition coefficient $<1000$ \\
Molecular weight & $<500 \mathrm{Da}$ \\
Melting point & $<200^{\circ} \mathrm{C}$ \\
pH of saturated aqueous solution & $\mathrm{pH} 5-9$ \\
Required dose deliverable & $<10 \mathrm{mg} /$ day \\
Irritation potential & No irritation to buccal tissue \\
\hline
\end{tabular}

Table 2: Choice of drug candidates for oral disintegrating tablets [15]

\begin{tabular}{ll}
\hline Suitable drug candidates for ODTs & Unsuitable drug candidates for ODTs \\
\hline No bitter taste & Short half-life and frequent dosing \\
Good stability in water and saliva & Drug having very bitter taste \\
Taken in small doses & Required controlled or sustained release \\
\hline
\end{tabular}

\section{The new generation of oral disintegrating tablets}

The first generation ODTs suffered from many undesirable traits, mainly low density, poor mechanical strength, brittleness and difficulty in handling. This necessitated blister packaging, which is not patient friendly, and causes increase in production expenses [16]. Another disadvantage of first generation ODTs was the difficulty of masking the taste of bitter active ingredients loaded within these tablets [17], which led to the emergence of new generation ODTs that overcame the problems of taste masking, allowed for modified release of medications, solved solubility and bioavailability problems, resulted in ODT tablets with excellent physical and mechanical robustness, mouth feel sensation, disintegration and dissolution properties.

\section{Challenges in formulating and developing oral disintegrating tablets}

There are several challenges in formulating and developing ODTs, such as: (1) palatability and acceptability [18], (2) mechanical strength [19], (3) the amount of drug that can be incorporated into an ODT system [19], (4) size of tablet [20], (5) hygroscopicity [21], (6) aqueous solubility [22, 23], (7) physical and chemical stability.

Taste-masking of bitter and unpleasant taste of drugs is essential in order to achieve patient acceptability and compliance. Different techniques were developed and introduced for bitterness masking [24-32]. One of the most commonly used techniques for tastemasking of bitter and unpleasant APIs or drugs is the coacervation process [33]. Coacervation process has successfully taste-masked a wide variety of bitter drugs, including but not limited to, acetaminophen, cetirizine, ibuprofen, pseudoephedrine, ranitidine, sumatriptan, theophylline and zolpidem [33]. Coupling controlled release behaviour with specialized functional polymers and efficient coating processes creates ODT systems with modified and sustained release profiles.

\section{Formulation processes for developing oral disintegrating tablets}

Various pharmaceutical techniques are used in the manufacture of ODTs, including: (1) freeze-drying or lyophilization [34], (2) spraydrying [35, 36], (3) molding [37, 38], (4) phase transition process [39], (5) melt-granulation [40-42], (6) sublimation [43, 44] (7) mass extrusion [45], (8) cotton candy process [46, 47], (9) nanonization [48], and (10) direct compression [40, 49-53]. Admittedly, direct compression is the most commonly used technique in the manufacture of ODTs, owing to its easy-implementation and cost-effectiveness [40, 53]. These techniques are described below in detail.

\section{Freeze-drying or lyophilization technique}

Freeze-drying, also known as lyophilization or cryodesiccation, is a technique that yields amorphous highly porous structures with rapid disintegration and dissolution. Orodispersible tablets made by lyophilization are prepared by dissolving the drug substance in an aqueous mixture of carrier/polymer, the solution is then poured into the holes of blister packs which are subsequently frozen in order to continue the freeze-drying cycle, followed by blistering and finally packaging. Lyophilization technique is very suitable for heatsensitive drugs (i.e. thermo-labile substances). Although ODTs prepared by freeze-drying process showed rapid disintegration and dissolution properties, but their industrial applications are limited since it is a high cost technique particularly in equipment and packing materials [34].

\section{Spray-drying technique}

Spray-drying is widely used in pharmaceutical industries nowadays. It provides a fast, efficient and economical way of removing solvents and producing free flowing, highly porous particles. In this process, gelatin is commonly used as a supporting agent, mannitol as a bulking agent, and sodium starch glycolate, crosscarmellose sodium and/or crospovidone as superdisintegrants. Orodispersible tablets made by spray-drying have been reported to disintegrate and dissolve in less than 20 seconds $[35,36]$.

Interestingly, Allen and Wang [54] fabricated a particulate support matrix for preparing ODTs by spray-drying, consisting of supporting agents of two polypeptide components from gelatin, a bulking agent (mannitol) and a volatilizing agent (ethyl alcohol). In order to maintain the net charges of both polypeptide components, a buffer system of an acidifying agent (citric acid) and an alkalinizing agent (sodium bicarbonate) is prepared and added to the tablet mixture. The mixture of the aforementioned components is then spray-dried to obtain porous granules. By incorporating a volatilizing agent as ethyl alcohol, the surface tension of the droplets is further reduced, and more porous structures are created. An effervescent agent could be optionally added to further enhance the dissolution.

\section{Molding method}

Molding is a solid dispersion method, involving the dispersion of APIs in an inert water-soluble carrier or matrix at solid-state form, prepared by solvent or heat method. Solvent method involves moistening the powder mixture with alcoholic or hydroalcoholic solvent, then molding into tablets under reduced pressure to form wet paste. This process is known as compression molding. The solvent is 
then removed from the wet paste by air-drying. The resulting tablets possess fine powders and highly porous structures. Solid dispersions are prepared directly from a molten matrix in which the drug is dispersed in or by vaporizing the solvent at ambient pressure (no vacuum lyophilization). The drug molecule can be in the form of discrete-particles or microparticles, completely or partially dispersed in the molten matrix. Because of their composition, molded tablets offer rapid disintegration, dissolution and improved taste, but they suffer the disadvantage of poor mechanical strength. Compared to freeze-drying, molded tablets are simpler in production and easier for industrial scale-up, although disintegration times may not be comparable to those of lyophilized forms $[37,38]$.

\section{Phase transition process}

This process involves a combination of low-and high melting point sugar alcohols. Optimizing the phase transition in the manufacturing process is important for formulating tablets without the need of any equipment. Kuno et al. [39] prepared ODTs by phase transition process using compressible powder mixture of erythritol (a sugar alcohol with melting point: $122^{\circ} \mathrm{C}$ ) and xylitol (a sugar alcohol with melting point: $93-95^{\circ} \mathrm{C}$ ), followed by heating at $93^{\circ} \mathrm{C}$ for a period of $15 \mathrm{~min}$. As a result of heating, the median pore size of tablets increased, as well as tablet hardness.

\section{Melt-granulation technique}

The melt-granulation technique is based on incorporating a hydrophilic melting binder in the formulation, which increases the physical resistance of tablets and helps their disintegration and dissolution. In comparison with other granulation techniques as dryand wet-granulation, melt-granulation is advantageous as no aqueous, alcoholic or even organic solvents are required. Meltgranulation is less time-consuming, cost-effective and easy to perform [40-42].

Interestingly, Abdelbary et al. [41] described a new approach for the preparation of ODTs of high mechanical strength involving the use of a hydrophilic waxy binder, PEG-6-stearate, commercially known as Superpolystate ${ }^{\circledR}$ by melt-granulation. Moreover, Agiba et al. [40] developed high-dose nutraceutical ODTs of glucosamine sulphate and chondroitin sulphate using a blend of hydrophilic melting binders as high molecular weight polyethylene glycols (PEG-4000 and PEG-6000). Although ODTs weighed around 1.30 gm with $60 \%$ drug load, they showed quick disintegration and dissolution properties, as well as a high mechanical strength.

\section{Sublimation method}

In this method, a sublimating agent like camphor is removed from the compressed tablets by sublimation. Highly porous structures are created as a result of removing camphor from the compressed tablets. The resulted tablets, characterized by high porous structures, could achieve fast disintegration in saliva. Examples of other volatile materials are adipic acid, ammonium carbonate, ammonium bicarbonate, arachidic acid, capric acid, camphor, menthol, myristic acid, and palmitic acid, thymol and urea. The sublimation temperature range is from 40 to $60^{\circ} \mathrm{C}[43,44]$.

Interestingly, Heinemann [55] prepared a highly porous tablet structure by using a mixture of volatile adjuvant, which was removed at the end by heating. On the other hand, Roser and Blair [56] removed the volatile materials by using vacuum, which reduced the dissolution-time from $15 \mathrm{~min}$ for the tablets containing trehalose (a disaccharide composed of 2 glucose units) alone to less than 1 minute. Moreover, Lo [57] developed an efficient method for the preparation of fast-dissolving tablets with highly porous structures.

\section{Mass extrusion technique}

In mass extrusion, the active and inactive ingredients are first softened using PEGs mixture and methanol as organic solvent, followed by extrusion and division into tablets using heated blades [45].

\section{Cotton candy process}

This technique involves the formation of a matrix of poly-or monosaccharides using flash melting and spinning to form floss like crystalline structure, which is then mixed with active/inactive ingredients and compressed into ODTs. This process can easily accommodate large doses of APIs with an improved mechanical strength. However, high-process temperature limits its use [46, 47].

\section{Nanonization}

Nanomelt is a recently developed nano-based drug delivery system, involving a reduction of drug particle size to be in nano-scale range by using a proprietary wet-milling technique. APIs usually present in the form of nanoparticles or nanocrystals are stabilized against possible agglomeration by surface adsorption onto preselected stabilizing agents incorporated into ODT systems. This technique is suitable for poorly water-soluble drugs, and the produced tablets exhibit rapid disintegration and dissolution [48].

\section{Direct compression}

Direct compression is the simplest, easiest and most widely used technique in ODT manufacturing, owing to its easy-implementation and cost-effectiveness. It involves using a blend of ingredients, which can provide rapid disintegration, as well as high physical integrity and stability. Sugar-based excipients as mannitol, sorbitol and lactose are commonly used as bulking agents, because of their high aqueous solubility and good taste-masking properties [40, 49-53].

In general, any tablet dosage form contains one or more of diluents/fillers, binders/adhesives, disintegrants, superdisintegrants, glidant/flowing agent and lubricant. Disintegrants and superdisintegrants are mainly incorporated into tablet formulations to promote their disintegration and dissolution. As the ability of the tablet to rapidly disintegrate is a prerequisite in ODT systems, ODTs usually contain high concentrations of disintegrants and superdisinetgrants. Examples of disintegrants and superdisintegrants are listed below.

\section{Disintegrants and superdisintegrants}

Various disintegrants and superdisintegrants are available in the pharmaceutical market and are readily used for the manufacture of ODTs.

\section{Starch and modified starch}

Starch is a versatile excipient with many applications in oral solid dosage forms as a diluent, binder, and disintegrant. Starch acts as a disintegrant at a concentration of $3-25 \%(w / w)$, with an optimum concentration of $15 \%(w / w)$ [58-61]. However, before using starch, a prior granulation step is required to avoid problems associated with low flowability and compressibility that can cause powder segregation. Examples of the most commonly used starches as disintegrants are maize, potato, rice, tapioca and wheat starch.

Directly compressible and modified starches have been introduced to overcome the problems associated with the conventional starches as pregelatinized starch (disintegrant) and sodium starch glycolate (superdisintegrant). Pregelatinized starch is a modified starch that has been mechanically and chemically modified through breaking all or part of the starch granules. Partially-pregelatinized starch, commercially known as Starch $1500^{\circledR}$ is a modified starch, mainly used in oral solid dosage forms as a diluent, binder [62,63] and disintegrant [64]. Comparing conventional starches with partiallypregelatinized starch, partially-pregelatinized starch has better flowability and compressibility; therefore, it may be used as a binder and disintegrant in direct compression. It also has self-lubricating property. However, when it is used with other excipients, the addition of a lubricant as magnesium stearate $(0.25 \%)(w / w)$ is necessary taking into consideration that concentrations greater than $0.25 \%(w / w)$ may have adverse effects on tablet disintegration and dissolution.

Sodium starch glycolate, commercially known as Explotab ${ }^{\circledR}$ or Primojel ${ }^{\circledR}$, is also used in oral solid dosage forms as a superdisintegrant. It is commonly used at a concentration of 2 to $8 \%$ $(\mathrm{w} / \mathrm{w})$, with an optimum concentration of $4 \%(\mathrm{w} / \mathrm{w})$ [58]. Disintegration occurs by rapid uptake of water followed by rapid swelling [65-67]. Increasing the tablet compression pressure did not seem to influence the disintegration time $[68,69]$. 


\section{Cellulose and modified cellulose}

Microcrystalline cellulose, commercially known as Avicel $\mathrm{PH}^{\circledR}$, is widely used in oral solid dosage forms as a binder or diluent in both direct-compression, dry-and wet-granulation methods, with some lubricant and disintegrant properties [58].

Croscarmellose sodium or cross-linked carboxymethylcellulose sodium, commercially known as Ac-Di-Sol ${ }^{\circledR}$, Explocel $^{\circledR}$ or Primellose ${ }^{\circledR}$ is widely used in oral solid dosage forms as a tablet superdisintegrant in both direct-compression, dry-and wetgranulations [58]. In wet-granulation, it can be added intra-and extragranularly, so that the wicking and swelling ability of the superdisintegrant is optimized $[70,71]$.

Low-substituted hydroxypropyl cellulose (L-HPC) is primarily used as a disintegrant in both dry-and wet-granulations, also used in the preparation of ODTs prepared by direct compression [58]. There are different grades of L-HPC that have different substitution levels and particle sizes. For example, LH-11 has the longest fibrous particles, and is typically used as a disintegrant for tablets prepared by direct compression method, while LH-21 is less fibrous and used in case of tablets prepared by wet-granulation method. LH-31 is a small particle size grade and mainly used in extrusion process to produce granules. LH-B1 is non-fibrous, high-density grade, typically produced for fluid-bed granulation. Low substitution grades LH-22 and LH-32 are usually used for enhancing the disintegration, and their concentrations are mainly depending on the characteristics of APIs [72]. The typical concentration of L-HPC in a solid formulation ranges from $5-50 \%(w / w)[58]$.

\section{Crospovidone [58]}

Crospovidone or cross-linked povidone (commercially known Kollidon CL-M ${ }^{\circledR}$; Polyplasdone $\mathrm{XL}^{\circledR}$ ) is a tablet superdisintegrant used at a concentration of $2-5 \%(\mathrm{w} / \mathrm{w})$ in tablets prepared by direct compression, dry-or wet-granulations [73]. Crospovidone can also be used as a solubility enhancer for increasing the solubility and dissolution of poorly absorbed drugs by coevaporation technique.

\section{Resin and its derivatives}

Ion exchange resins have been introduced as tablet disintegrants. The most commonly used ion exchange resin is polacrilin potassium. Polacrilin potassium is a highly hydrophilic cation exchange resin having good swelling properties [74] as well as wicking and strain recovery characteristics $[75,76]$. It is usually used in a concentration of $2-10 \%(\mathrm{w} / \mathrm{w})$ in tablet formulations, although $2 \%(\mathrm{w} / \mathrm{w})$ was reported to be sufficient.

\section{Mechanisms of disintegrants}

\section{Swelling}

The most common mechanism of tablet disintegration is swelling. Swelling is basically a dimensional-expansion process in which particles enlarge in every direction to push apart tablet components, thereby initiating the process of breaking-up of the tablet matrix [77, 78]. The swelling property of a disintegrant depends on many factors including chemical structure and degree of crosslinking [79]. Porosity of the tablet compact plays also a significant role in determining the performance rate of swelling disintegrants. A tablet matrix with low porosity and void spaces would reduce liquid penetration and thereby delay or prolong the disintegration time, and vice versa [77]. Therefore, tablets should be prepared at an optimal porosity to provide adequate mechanical integrity and good disintegrability [80]. There is a positive correlation between the disintegration force development rate and the disintegration time, while there is no correlation between the extent of swelling of a disintegrant and the maximum disintegration force. Thus, the disintegration force development rate is essential for rapid tablet matrix disintegration [80]

\section{Wicking (capillary action)}

Wicking is a process of liquid penetration by capillary action into the microstructured spaces in the tablet compact to displace the entrapped air (i.e. through porous structures within the tablet compact) $[77,81,82]$. As other water-soluble ingredients rather than disintegrants can contribute to improving disintegration by increasing tablet porosity as high-molecular weight polyethylene glycols, so wicking cannot be classified as a primary disintegration mechanism. However, water penetration into the tablet compact is essential for disintegrant activation [79]. Thus, the penetration rate will mainly depend on the balance between capillary and opposite viscous forces [83].

\section{Strain recovery (process of deformation)}

In tabletting process, tablet components are subjected to a high compaction pressure. During compaction, particles deform and interparticulate bonds are disturbed. Strain recovery is a reversible viscoelastic deformation process [84]. It elucidates the process of mechanical activation of disintegrant polymer chains when getting into contact with the aqueous media, causing a partial recovery into their original shapes [77]. Moreover, disintegration media contributes to the plasticization of disintegrant polymer chains and assists their accommodation into the most energetically stable positions. The resulting pressure could help in tablet disintegration [79]. Strain recovery process is unidirectional and exists in the opposite direction of exerted compaction force [78]. The recovery and relaxation of the stressed particles promotes rapid movement and volume expansion, causing the breakage of bonding bonds.

\section{Interruption of particle-particle bonds}

Interruption of particle-particle bonds is considered one of the most important mechanisms for tablet disintegration. Some previous studies suggested three different possible bonding mechanisms involved in tableting which are solid bridges, mechanical interlocking, and intermolecular forces [85]. Among those three bonding mechanisms, intermolecular forces are considered the most prevalent bonding mechanism in tablet disintegration $[85,86]$. Various techniques have been introduced to identify the intermolecular bonds involved in the interruption of the tablet matrix. Luangtana-Anan et al. [87] showed a correlation between the intermolecular forces present in tablets and the disintegration time.

\section{Heat of interaction}

Two types of interactions result from the interaction of materials with aqueous media; endothermic (heat absorption) and exothermic (heat generation) [77]. Exothermic interactions are obtained from interacting disintegrants with the aqueous media, either water or buffer compartment [88], hence the heat generated causes localized stress within tablets which is usually associated with an expansion of air retained in the tablet compact, and subsequently increased disintegration time. Lowenthal [87] illustrated the importance of heat generation as an important mechanism in tablet disintegration. However, Luangtana-Anan et al. [88] explained the changes in enthalpy for different disintegrants and concluded that the amount of heat generated by wetting is rather small and insufficient to cause effective expansion of the entrapped air in the tablet compact. Furthermore, Caramella et al. [89] studied the relation between the temperature of the disintegration media and disintegration time and concluded that increasing the temperature of the aqueous media did not necessarily improve the disintegration process. Therefore, it is necessary to further study the mechanism of heat of interactions to identify its impact on tablet disintegration.

\section{Coprocessed and multifunctional excipients}

Developing a robust tablet formulation that can be easily scaled up to a drug product without any problematic issues is a big challenge. Today, there are many challenges in product manufacturing and scaling up; therefore, the need of new pharmaceutical techniques and novel excipients are necessary for manufacturing a high-quality product. Coprocessed and multifunctional excipients are designed to improve the formulation experience and performance. They are high-functionality excipients containing one or more diluents, binders, disintegrants, superdisintegrants and/or lubricants that could provide superior binding, high mechanical strength, quick disintegration and dissolution. The basic principle of coprocessing is based on particle engineering technologies. Any powdered substance is characterized by three different levels of solid-state; 
molecular level (individual molecule level), particle level (individual solid particle level) and bulk level (as assembly of particulate species) [90]. These different levels are closely connected to each other in which changing in one level affects the other levels. The molecular level involves the arrangement of individual molecules in the crystal lattice and represented by polymorphism, pseudopolymorphism, and the amorphous state. Particle level involves individual solid particle properties like arrangement, shape, size, surface area, and porosity. The bulk level involves large numbers of particles together and their properties like flowability and compressibility. All these levels are essential for evaluating the performance of excipients.

Methods of coprocessing include spray-drying, granulation, extrusion/spheronization, melt-extrusion, solvent-evaporation and crystallization. Examples of commonly used coprocessed and multifunctional excipients are listed in table 3. Coprocessed and multifunctional excipients represent the ultimate solution in developing orodispersible tablets with very few excipients and high functionalities and physicomechanical properties.

Table 3: The most common examples of high-functionality excipients

\begin{tabular}{|c|c|c|}
\hline Excipient & Composition & Manufacturer \\
\hline Prosolv ${ }^{\circledR}$ SMCC & Silicifed Microcrystalline Cellulose & JRS Pharma \\
\hline \multirow[t]{4}{*}{ Prosolv $^{\circledR}$ EASYtab SP } & Microcrystalline Cellulose & JRS Pharma \\
\hline & Colloidal Silicon Dioxide & \\
\hline & Sodium Starch Glycolate & \\
\hline & Sodium Stearyl Fumarate & \\
\hline \multirow[t]{4}{*}{ Prosolv ${ }^{\circledR}$ EASYtab Nutra CM } & Microcrystalline Cellulose & JRS Pharma \\
\hline & Silicon Dioxide & \\
\hline & Croscarmellose Sodium & \\
\hline & Magnesium Stearate & \\
\hline \multirow[t]{4}{*}{ Prosolv ${ }^{\circledR}$ EASYtab Nutra GM } & Microcrystalline Cellulose & JRS Pharma \\
\hline & Silicon Dioxide & \\
\hline & Sodium Starch Glycolate & \\
\hline & Magnesium Stearate & \\
\hline \multirow[t]{4}{*}{ Prosolv ${ }^{\circledR}$ EASYtab Nutra CP } & Microcrystalline Cellulose & JRS Pharma \\
\hline & Silicon Dioxide & \\
\hline & Croscarmellose Sodium & \\
\hline & Sodium Stearyl Fumarate & \\
\hline \multirow[t]{5}{*}{ Prosolv $^{\circledR}$ ODT G2 } & Microcrystalline Cellulose & JRS Pharma \\
\hline & Silicon Dioxide & \\
\hline & Mannitol & \\
\hline & Fructose & \\
\hline & Crospovidone & \\
\hline Mannogem ${ }^{\circledR}$ EZ & Spray-dried Mannitol & SPI Pharma \\
\hline Mannogem ${ }^{\circledR} \mathrm{XL}$ & Spray-dried Mannitol & SPI Pharma \\
\hline Compressol $^{\circledR} \mathrm{SM}$ & Mannitol, Sorbitol & SPI Pharma \\
\hline Advantose $^{\circledR} 100$ & Spray-dried Maltose & SPI Pharma \\
\hline Advantose ${ }^{\circledR}$ FS95 & Spray-dried Fructose & SPI Pharma \\
\hline Lubripharm ${ }^{\circledR}$ SSF & Sodium Stearyl Fumarate & SPI Pharma \\
\hline \multirow[t]{4}{*}{ Pharmaburst $^{\circledR}$ C1 } & Mannitol & SPI Pharma \\
\hline & Sorbitol & \\
\hline & Crosspovidone & \\
\hline & Colloidal silicone dioxide & \\
\hline Tabulose ${ }^{\circledR}$ & Colloidal Microcrystalline Cellulose & Roquette Pharma \\
\hline Pearlitol ${ }^{\circledR}$ & Spray-dried Mannitol & Roquette Pharma \\
\hline Pearlitol ${ }^{\circledR}$ Flash & Mannitol, Starch & Roquette Pharma \\
\hline Starlac $^{\circledR}$ & Starch, Lactose & Roquette Pharma \\
\hline Xylisorb $^{\circledR}$ & Xylitol & Roquette Pharma \\
\hline \multirow[t]{3}{*}{ Ludipress $^{\circledR}$} & Lactose & BASF Pharma \\
\hline & Povidone & \\
\hline & Crospovidone & \\
\hline \multirow[t]{4}{*}{ Ludiflash $^{\circledR}$} & D-mannitol & BASF Pharma \\
\hline & Crospovidone & \\
\hline & Polyvinyl acetate & \\
\hline & Povidone & \\
\hline \multirow[t]{3}{*}{ Soluplus ${ }^{\circledR}$} & Polyethylene glycol & BASF Pharma \\
\hline & polyvinyl acetate & \\
\hline & Polyvinylcaprolactame & \\
\hline \multirow[t]{2}{*}{ Sepitrap $^{\mathrm{TM}} 80$} & Magnesium Aluminometasilicate & SEPPIC \\
\hline & Polysorbate 80 & \\
\hline \multirow[t]{2}{*}{ Sepitrab $^{\text {TM }} 4000$} & Magnesium Aluminometasilicate & SEPPIC \\
\hline & Polyoxyl 40 Hydrogenated Castor Oil & \\
\hline $\mathrm{HiCel}^{\top M} \mathrm{HFE}$ & Microcrystalline Cellulose, Mannitol & Sigachi Industries Pvt. Ltd \\
\hline $\mathrm{HiCel}^{\mathrm{TM}} \mathrm{CE} 15$ & Microcrystalline Cellulose, Guar gum & Sigachi Industries Pvt. Ltd \\
\hline \multirow[t]{2}{*}{$\mathrm{HiCel}^{\mathrm{TM}} \mathrm{SMCC}$} & Microcrystalline Cellulose & Sigachi Industries Pvt. Ltd \\
\hline & Colloidal Silicon dioxide & \\
\hline \multirow[t]{2}{*}{ HiCellac $^{\mathrm{TM}} 80$ and 100} & Microcrystalline Cellulose & Sigachi Industries Pvt. Ltd \\
\hline & Lactose Monohydrate & \\
\hline \multirow[t]{2}{*}{$\mathrm{HiCel}^{\mathrm{TM}} \mathrm{DG}$} & Microcrystalline Cellulose & Sigachi Industries Pvt. Ltd \\
\hline & Dicalcium phosphate & \\
\hline
\end{tabular}




\section{Patented technologies}

Several patented technologies are introduced for the manufacture of ODTs [14, 25, 53], including: (1) Zydis ${ }^{\circledR}$ technology [22], (2) Lyoc ${ }^{\circledR}$ technology [92], (3) WowTab ${ }^{\circledR}$ technology [93, 94], (4) FlashTab $^{\circledR}$ technology and Multiflash ${ }^{\circledR}$ [49], (5) Durasolv ${ }^{\circledR}$ and Orasolv $^{\circledR}$ technologies [95, 96], (6) Frosta ${ }^{\circledR}$ technology [14], (7)
AdvaTab $^{\circledR}$ technology [97], (8) FlashDose ${ }^{\circledR}$ technology [98], (9) OraQuick $^{\circledR}$ technology [14], (10) Nanocrystal ${ }^{\circledR}$ and EFVDAS ${ }^{\circledR}$ and FastMelt ${ }^{\circledR}$ technologies [14, 99], (11) QuickDis ${ }^{\circledR}$ technology, and (12) Pharmabrust ${ }^{\mathrm{TM}}$ technology [14]. Table 4 summarizes the patented techniques used for the manufacture of ODTs and table 5 shows examples of globally marketed oral disintegrating tablets products.

Table 4: Patented technologies used to produce ODTs

\begin{tabular}{|c|c|c|c|c|c|}
\hline Technology & Company & Description & Novelty aspect & Advantages & Disadvantages \\
\hline Zydis $^{\circledR}[22]$ & $\begin{array}{l}\text { R. P. Scherer } \\
\text { Corporation }\end{array}$ & $\begin{array}{l}\text { - Lyophilizing the drug in a water-soluble } \\
\text { matrix usually consisting of mannitol (a } \\
\text { crystalline sugar) and gelatin (a water- } \\
\text { soluble polymer). } \\
\text { - Other excipients can be used depending on } \\
\text { the properties of the drug. }\end{array}$ & $\begin{array}{l}\text { First marketed } \\
\text { new tablet } \\
\text { technology }\end{array}$ & $\begin{array}{l}\text { - Self- } \\
\text { preservative } \\
\text { - Rapid } \\
\text { disintegration } \\
\text { and dissolution } \\
\text { - Improved } \\
\text { bioavailability }\end{array}$ & $\begin{array}{l}\text { - Expensive manufacturing } \\
\text { process } \\
\text { - Require special packaging } \\
\text { materials } \\
\text { - Unstable at higher } \\
\text { temperature and humidity } \\
\text { - Incompatible with high } \\
\text { drug doses }\end{array}$ \\
\hline Lyoc $^{\circledR}[92]$ & $\begin{array}{l}\text { Cephalon } \\
\text { Corporation }\end{array}$ & $\begin{array}{l}\text { - A freeze drying process but differ from } \\
\text { Zydis where the drug product is frozen on } \\
\text { freeze dryer shelves. } \\
\text { - The homogeneous liquid or suspension is } \\
\text { placed into blister cavities and subjected to } \\
\text { freeze drying. } \\
\text { - The homogenous liquid or suspension } \\
\text { contains one or more of water-soluble fillers, } \\
\text { thickening agents, surfactants and the drug } \\
\text { substance. }\end{array}$ & $\begin{array}{l}\text { A modified } \\
\text { form of Zydis }\end{array}$ & $\begin{array}{l}\text { - Self- } \\
\text { preservative }\end{array}$ & $\begin{array}{l}\text { - Expensive manufacturing } \\
\text { process } \\
\text { - Require high amounts of } \\
\text { fillers to prevent possible } \\
\text { sedimentation } \\
\text { - The high amounts of fillers } \\
\text { can reduce tablet porosity } \\
\text { and prolong disintegration } \\
\text { - Incompatible with high } \\
\text { drug doses }\end{array}$ \\
\hline $\begin{array}{l}\text { WowTab }^{\circledR} \\
{[93,94]}\end{array}$ & $\begin{array}{l}\text { Yamanouchi } \\
\text { Pharma } \\
\text { Technologie } \\
\text { s }\end{array}$ & $\begin{array}{l}\text { - Wow means without water } \\
\text { - This process involves granulating low- } \\
\text { moldable sugars (e. g. mannitol, lactose, } \\
\text { sucrose and glucose) that show rapid } \\
\text { dissolution with high-moldable sugars (e. g. } \\
\text { sorbitol, maltitol and maltose) with the drug } \\
\text { substance. }\end{array}$ & $\begin{array}{l}\text { Combination of } \\
\text { low-and high- } \\
\text { moldable sugars }\end{array}$ & $\begin{array}{l}\text { - Rapid } \\
\text { disintegration } \\
\text { and dissolution }\end{array}$ & $\begin{array}{l}\text { - No significant change in } \\
\text { drug bioavailability }\end{array}$ \\
\hline $\begin{array}{l}\text { FlashTab } \\
{[49]}\end{array}$ & $\begin{array}{l}\text { Prographar } \\
\text { m }\end{array}$ & $\begin{array}{l}\text { - This process involves coating a drug with a } \\
\text { polymer as Eudragit to provide a rapid drug } \\
\text { release in the stomach and formulating this } \\
\text { microencapsulated drug with an effervescent } \\
\text { base to produce a flash dispersible tablet. } \\
\text { - This technology comprises the granulation } \\
\text { of a drug and excipients by either dry-or wet- } \\
\text { granulation then compressed into tablets. }\end{array}$ & $\begin{array}{l}\text { A compressed } \\
\text { tablet dosage } \\
\text { form containing } \\
\text { a drug as } \\
\text { microcrystals or } \\
\text { microgranules }\end{array}$ & $\begin{array}{l}\text { - Conventional } \\
\text { tabletting } \\
\text { process } \\
\text { - Easy to } \\
\text { perform } \\
\text { - Tablets } \\
\text { dissolve within } \\
1 \text { minute. }\end{array}$ & --- \\
\hline $\begin{array}{l}\text { DuraSolv }^{\circledR} \\
{[95,96]}\end{array}$ & $\begin{array}{l}\text { Cima Labs, } \\
\text { Inc. }\end{array}$ & $\begin{array}{l}\text { - Conventional tabletting process (i.e. a } \\
\text { direct compression method using higher } \\
\text { compaction pressures during tabletting) }\end{array}$ & $\begin{array}{l}\text { Second } \\
\text { generation oral } \\
\text { disintegrating } \\
\text { tablets }\end{array}$ & $\begin{array}{l}\text { - Higher } \\
\text { mechanical } \\
\text { - strength than } \\
\text { Orasolv } \\
\text { - Good tablet } \\
\text { rigidity } \\
\text { - Easy to } \\
\text { perform } \\
\text { - Low cost } \\
\text { - Packaged in } \\
\text { blisters, foil or } \\
\text { bottles }\end{array}$ & $\begin{array}{l}\text { - Incompatible with high } \\
\text { drug doses because the } \\
\text { formulations are subjected } \\
\text { to high compaction } \\
\text { pressures. Unlike OraSolv, } \\
\text { the structural integrity of } \\
\text { any taste-masking may be } \\
\text { compromised with high drug } \\
\text { doses. } \\
\text { - No significant change in } \\
\text { drug bioavailability }\end{array}$ \\
\hline $\begin{array}{l}\text { OraSolv }{ }^{\circledR} \\
{[95,96]}\end{array}$ & & $\begin{array}{l}\text { - Conventional tabletting process (i.e. direct } \\
\text { compression method using an effervescent } \\
\text { base and taste masked drug.) } \\
\text { - Effervescence agents cause the tablet to } \\
\text { disintegrate rapidly in less than } 1 \text { min once } \\
\text { contact with water or saliva, leaving coated } \\
\text { drug powder. } \\
\text { - Effervescent agents include carbonates such } \\
\text { as sodium bicarbonate, sodium carbonate, } \\
\text { potassium bicarbonate and potassium } \\
\text { carbonate, magnesium carbonate, and acids } \\
\text { like citric, tartaric, fumaric, adipic and succinic. }\end{array}$ & $\begin{array}{l}\text { Unique taste- } \\
\text { masking } \\
\text { process }\end{array}$ & $\begin{array}{l}\text { - Taste- } \\
\text { masking is two- } \\
\text { fold } \\
\text { - Rapid } \\
\text { dissolution }\end{array}$ & $\begin{array}{l}\text { - Low mechanical strength } \\
\text { - Soft and fragile } \\
\text { - Tablets; therefore, a } \\
\text { special packing material } \\
\text { system is required } \\
\text { - No significant change in } \\
\text { drug bioavailability }\end{array}$ \\
\hline Frosta $^{\circledR}[14$ & Akina & $\begin{array}{l}\text { - This technique comprises formulating } \\
\text { plastic granules and compressing them at low } \\
\text { compaction pressure to produce tablets with } \\
\text { high porosity }\end{array}$ & $\begin{array}{l}\text { Formation of } \\
\text { highly porous, } \\
\text { plastic granules }\end{array}$ & $\begin{array}{l}\text { - High } \\
\text { mechanical } \\
\text { strength } \\
\text { - Rapid }\end{array}$ & --- \\
\hline
\end{tabular}




\begin{tabular}{|c|c|c|c|c|c|}
\hline & & $\begin{array}{l}\text { - Plastic granules may contain porous and } \\
\text { plastic materials, penetration enhancers and } \\
\text { binders } \\
\text { - The manufacturing process includes mixing } \\
\text { the porous plastic materials with penetration } \\
\text { enhancers, followed by granulating with the } \\
\text { aid of binders }\end{array}$ & & disintegration & \\
\hline $\begin{array}{l}\text { AdvaTab }^{\circledR} \\
{[97]}\end{array}$ & Eurand & $\begin{array}{l}\text { - A microencapsulation process for coating } \\
\text { the drug particles with gastro soluble } \\
\text { polymer to mask the bitter taste along and } \\
\text { prevent the drug dissolution in mouth cavity. } \\
\text { - It can be combined with Eurand's } \\
\text { complimentary particle technologies as } \\
\text { Microcaps }{ }^{\circledR} \text { (taste-masking technology) and } \\
\text { Diffucaps }^{\circledR} \text { (controlled release technology). }\end{array}$ & $\begin{array}{l}\text { A } \\
\text { microencapsula } \\
\text { tion process }\end{array}$ & $\begin{array}{l}\text { - Rapid } \\
\text { disintegration } \\
\text { in mouth cavity, } \\
\text { typically within } \\
30 \text { seconds }\end{array}$ & --- \\
\hline $\begin{array}{l}\text { FlashDose }^{\circledR} \\
\text { [98] }\end{array}$ & $\begin{array}{l}\text { Fuisz } \\
\text { Technologie } \\
\text { s, Ltd. }\end{array}$ & $\begin{array}{l}\text { - This technique comprises a unique spinning } \\
\text { mechanism to produce a floss-like crystalline } \\
\text { structure, much like cotton candy process. } \\
\text { - This crystalline sugar-based matrix (floss) } \\
\text { can incorporate the active drug and be } \\
\text { compressed into tablets. } \\
\text { - Instead of a floss-like crystalline sugar, } \\
\text { small spheres of saccharides can be used as a } \\
\text { carrier for the drug. }\end{array}$ & $\begin{array}{l}\text { A unique } \\
\text { spinning } \\
\text { mechanism and } \\
\text { an alternative } \\
\text { method of taste } \\
\text { masking }\end{array}$ & $\begin{array}{l}\text { - Good taste- } \\
\text { masking } \\
\text { - High surface } \\
\text { area for drug } \\
\text { dissolution }\end{array}$ & $\begin{array}{l}\text { - Require special packing } \\
\text { materials as tablets are } \\
\text { highly friable. } \\
\text { - Require high temperature } \\
\text { to melt the matrix; therefore, } \\
\text { it cannot be used with heat } \\
\text { and moisture sensitive drugs } \\
\text { - It is suitable for doses up } \\
\text { to } 600 \mathrm{mg}\end{array}$ \\
\hline $\begin{array}{l}\text { OraQuick }{ }^{\circledR}[ \\
14]\end{array}$ & $\begin{array}{l}\text { KV } \\
\text { Pharmaceut } \\
\text { ical Co., Inc. }\end{array}$ & $\begin{array}{l}\text { - Taste masking process is done by } \\
\text { incorporating drug into matrix microsphere. } \\
\text { - In this technique, tablets are prepared by } \\
\text { dissolving the sugar (e. g. mannitol, sorbitol } \\
\text { or sucrose) and protein (gelatin or albumin) } \\
\text { in a aqueous, alcoholic or hydroalcoholic } \\
\text { solvent. The matrix is then spray dried, } \\
\text { yielding highly porous granules. } \\
\text { - The formed granules are mixed with the } \\
\text { drug and other excipients then compressed } \\
\text { at low compression force. }\end{array}$ & $\begin{array}{l}\text { Unique taste- } \\
\text { masking } \\
\text { process } \\
\text { (microencapsul } \\
\text { ated drug } \\
\text { particles) }\end{array}$ & $\begin{array}{l}\text { - appropriate } \\
\text { for heat- } \\
\text { sensitive } \\
\text { drugs }\end{array}$ & --- \\
\hline $\begin{array}{l}\text { NanoCryst } \\
\mathrm{al}{ }^{\circledR}[14]\end{array}$ & $\begin{array}{l}\text { Elan } \\
\text { Corporation }\end{array}$ & $\begin{array}{l}\text { - The main concept of this technology is } \\
\text { decreasing drug particle size and increasing } \\
\text { surface area for drug absorption. } \\
\text { - Nanocrystal particles are small particles of } \\
\text { the drug substance, typically less than } 1000 \\
\text { nm in diameter, which are } \\
\text { - Manufactured by milling the drug substance } \\
\text { using a suitable wet-milling method. } \\
\text { - Nanocrystal colloidal dispersions of drug } \\
\text { substances have been combined with water- } \\
\text { soluble ingredients as mannitol and sorbitol, } \\
\text { filled into blisters, and freeze-dried. The } \\
\text { resultant blisters are remarkably robust yet } \\
\text { dissolve in very small quantities of water in } \\
\text { matter of seconds. This approach is suitable } \\
\text { with highly potent or hazardous materials. }\end{array}$ & $\begin{array}{l}\text { Wet-milling } \\
\text { technique }\end{array}$ & $\begin{array}{l}\text { - Easy to } \\
\text { perform } \\
\text { - Cost-effective } \\
\text { manufacturing } \\
\text { process } \\
\text { - Use } \\
\text { conventional } \\
\text { packaging } \\
\text { materials } \\
\text { - suitable for } \\
\text { doses up to } 200 \\
\text { mg of API per } \\
\text { unit }\end{array}$ & --- \\
\hline $\begin{array}{l}\operatorname{EFVDAS}^{\circledR}[1 \\
4]\end{array}$ & & $\begin{array}{l}\text { - Known as Effervescent Drug Absorption } \\
\text { System (EFVDAS) } \\
\text { - Examples of EFVDAS products are } \\
\text { acetaminophen, cimetidine, ibuprofen and } \\
\text { naproxen. }\end{array}$ & $\begin{array}{l}\text { Effervescent } \\
\text { Drug } \\
\text { Absorption } \\
\text { System }\end{array}$ & $\begin{array}{l}\text { - Used for OTC } \\
\text { and } \\
\text { prescription } \\
\text { drugs } \\
\text { - Also, for hot } \\
\text { drink sachet } \\
\text { products }\end{array}$ & \\
\hline $\begin{array}{l}\text { Fast Melt }{ }^{\circledR} \\
{[14]}\end{array}$ & & $\begin{array}{l}\text { - Combine the advantages of liquid } \\
\text { formulations with those of solid dosage } \\
\text { forms } \\
\text { - Characterized by highly porous, micro-fine } \\
\text { matrix tablet } \\
\text { - Once placed onto the oral cavity, the } \\
\text { matrix tablet rapidly absorbs water and } \\
\text { disintegrates, and the drug is released into } \\
\text { the oral cavity. }\end{array}$ & $\begin{array}{l}\text { Highly porous, } \\
\text { micro-fine } \\
\text { matrix tablet }\end{array}$ & --- & --- \\
\hline $\begin{array}{l}\text { Pharmabru } \\
\mathrm{st}^{\mathrm{TM}}[14]\end{array}$ & SPI Pharm & $\begin{array}{l}\text { - Tablets are manufactured by direct } \\
\text { compression of drug substances, } \\
\text { pharmabrust, flavours, colorants and a } \\
\text { lubricant. } \\
\text { - Tablets dissolve within } 30-40 \text { seconds. } \\
\text { - Tablets have sufficient strength and can be } \\
\text { packed in blister packs and bottles }\end{array}$ & $\begin{array}{l}\text { Direct } \\
\text { compression } \\
\text { using } \\
\text { Pharmabrust as } \\
\text { a novel } \\
\text { multifunctional } \\
\text { excipient }\end{array}$ & --- & --- \\
\hline
\end{tabular}


Table 5: A list of marketed orally disintegrating tablet products

\begin{tabular}{|c|c|c|c|c|}
\hline Commercial product & Active ingredient & Indication & Manufacturer & Technology \\
\hline Abilify ${ }^{\circledR}$ & Aripiprazole & Anti-psychotic & $\begin{array}{l}\text { Otsuka America } \\
\text { Pharmaceutical, Inc. }\end{array}$ & Zydis $^{\circledR}$ \\
\hline Children's Dimetapp ${ }^{\circledR}$ ND & Loratadine & Anti-histaminic & Wyeth Consumer Healthcare & \\
\hline Claritin $^{\circledR}$ RediTabs $^{\circledR}$ & Loratadine & Anti-histaminic & Bayern Schering Corporation & \\
\hline Feldene Melt $^{\mathrm{TM}}$ & Piroxicam & Anti-inflammatory & Pfizer & \\
\hline Grastek $^{\circledR}$ Sublingual Tablets & $\begin{array}{l}\text { Pollen allergen extract from } \\
\text { Timothy grass (Phleum } \\
\text { pratense) }\end{array}$ & $\begin{array}{l}\text { Timothy grass or related } \\
\text { grass-pollen allergies }\end{array}$ & $\begin{array}{l}\text { Catalent Pharma Solutions } \\
\text { for ALK-Abelló A/S }\end{array}$ & \\
\hline $\begin{array}{l}\text { Grazax 75,000 SQ-T Oral } \\
\text { Lyophilisate }\end{array}$ & $\begin{array}{l}\text { Pollen allergen extract from } \\
\text { Timothy grass (Phleum } \\
\text { pratense) }\end{array}$ & $\begin{array}{l}\text { Timothy grass or related } \\
\text { grass-pollen allergies }\end{array}$ & ALK-Abelló A/S & \\
\hline $\begin{array}{l}\text { Imodium }{ }^{\circledR} \text { Instant } \\
\text { Melts/Imodium }{ }^{\circledR} \text { Lingual/ } \\
\text { Imodium }{ }^{\circledR} \text { Quick Dissolve }\end{array}$ & Loperamide $\mathrm{HCl}$ & Anti-diarrheal & Johnson and Johnson & \\
\hline Klonopin ${ }^{\circledR}$ Wafers & Clonazepam & $\begin{array}{l}\text { Anti-convulsive and } \\
\text { Anxiolytic }\end{array}$ & Roche & \\
\hline Maxalt-MLT ${ }^{\circledR}$ & Rizatritpan benzoate & Anti-migraine & Merck & \\
\hline Motilium $^{\circledR}$ & Domperidone & Anti-emetic & Johnson and Johnson & \\
\hline Ondansetron-RL Zydis ${ }^{\circledR}$ Wafers & Ondansetron $\mathrm{HCl}$ & Anti-emetic & GlaxoSmithKline & \\
\hline Ondaz Zydis ${ }^{\circledR}$ Wafers & Ondansetron $\mathrm{HCl}$ & Anti-emetic & Sandoz & \\
\hline Pepcid $^{\circledR}$ & Famotidine & Anti-ulcer & Merck & \\
\hline Ragwitek $^{\circledR}$ Sublingual Tablets & $\begin{array}{l}\text { Pollen allergen extract from } \\
\text { Short Ragweed (Ambrosia } \\
\text { artemisiifolia) }\end{array}$ & Ragweed pollen allergies & ALK-Abelló A/S & \\
\hline Risperdal ${ }^{\circledR}{\mathrm{M}-\mathrm{Tab}^{\mathrm{TM}}}$ & Risperidone & Anti-psychotic & Johnson and Johnson & \\
\hline Zelapar $^{\text {m }}$ & Selegiline $\mathrm{HCl}$ & Parkinson's disease & Elan/Amarin Corporation & \\
\hline Zofran $^{\circledR}$ ODT & Ondansetron $\mathrm{HCl}$ & Anti-emetic & GlaxoSmithKline & \\
\hline Zubrin $^{\circledR}$ & Tepoxalin & Anti-inflammatory & Schering Corporation & \\
\hline Zyprexa ${ }^{\circledR}$ & Olanzapine & Anti-psychotic & Eli Lilly & \\
\hline Loperamide $^{\circledR}$ Lyoc $^{\circledR}$ & Loperamide chlorhydrate & Anti-diarrheal & Teva & Lyco $^{\circledR}$ \\
\hline Paralyoc $^{\circledR}$ & Paracetamol & Analgesic, anti-pyretic & Teva & \\
\hline Proxalyoc $^{\circledR}$ & Piroxicam & Anti-inflammatory & Teva & \\
\hline Seglor ${ }^{\circledR}$ Lyoc $^{\circledR}$ & Dihydroergotamine mesylate & Migraine & UCB Pharma & \\
\hline Sermion $^{\circledR}$ Lyco $^{\circledR}$ & Nicergoline & Potent vasodilator & Pfizer & \\
\hline Spasponlyoc ${ }^{\circledR}$ & Phloroglucinol dihydrate & Anti-spasmodic & Teva & \\
\hline Vogalene ${ }^{\circledR}$ Lyoc $^{\circledR}$ & Metopimazine & Anti-emetic & Teva & \\
\hline Reminly ${ }^{\circledR}$ OD Tablets & Galantamine & Alzheimer's disease & Janssen/Takeda & Quicksolv ${ }^{\circledR}$ \\
\hline Risperdal ${ }^{\circledR}$ M-Tab & Risperidone & Anti-psychotic & Janssen Pharma & \\
\hline Allegra $^{\circledR}$ & Fexofenadine & Anti-histaminic & Aventis Pharmaceuticals & OraSolv $^{\circledR}$ \\
\hline Clarinex RediTab ${ }^{\circledR}$ & Desloratadine & Anti-histaminic & Schering-Plough & \\
\hline Fluxid $^{\mathrm{TM}}$ & Famotidine & Anti-ulcer & Azur Pharma & \\
\hline Orapred $^{\circledR}$ ODT & Prednisolone sodium phosphate & Asthma & Concordia Pharmaceuticals & \\
\hline Remeron ${ }^{\circledR}$ SolTab & Mirtazapine & Anti-depressant & Organon Inc. & \\
\hline $\begin{array}{l}\text { Tempra }{ }^{\circledR} \text { Quicklets/ } \\
\text { Tempra }{ }^{\circledR} \text { FirsTabs }\end{array}$ & Acetaminophen & Analgesic & Bristol-Myers Squibb & \\
\hline $\begin{array}{l}\text { Triaminic }{ }^{\circledR} \text { Cold Cough } \\
\text { Softchews }\end{array}$ & $\begin{array}{l}\text { Chlorpheniramine maleate, } \\
\text { Dextromethorphan } \mathrm{HBr} \text {, } \\
\text { Pseudoephedrine } \mathrm{HCl}\end{array}$ & Cold cough & Novartis Consumer Health & \\
\hline Zomig ${ }^{\circledR}$ Rapimelt & Zolmitriptan & Migraine & AstraZeneca & \\
\hline Alavert $^{\circledR}$ & Loratadine & Anti-histaminic & Wyeth Consumer Healthcare & DuraSolv $^{\circledR}$ \\
\hline Dimetapp $^{\circledR}$ ND & Loratadine & Anti-histaminic & Wyeth Consumer Healthcare & \\
\hline $\begin{array}{l}\text { FazaClo }^{\circledR} \text { LD (low dose) } \\
\text { and FazaClo }{ }^{\circledR} \text { HD (high dose) }\end{array}$ & Clozapine & Schizophrenia & Alamo Pharmaceuticals & \\
\hline Kemstro $^{T M}$ & Baclofen & Anti-spastic analgesic & Schwarz Pharma & \\
\hline Niravam $^{\mathrm{TM}}$ & Alprazolam & Anxiety & Schwarz Pharma & \\
\hline $\mathrm{NuLev}^{\circledR}$ & Hyoscyamine sulfate & Antispasmodic & Schwarz Pharma & \\
\hline Benadryl ${ }^{\circledR}$ Fastmelt & Diphenhydramine Citrate & Anti-histaminic & Pfizer & WowTab ${ }^{\circledR}$ \\
\hline Gaster ${ }^{\circledR} \mathrm{D}$ & Famotidine & Anti-ulcer & Yamanouchi & \\
\hline Harnal $^{\circledR}$ D & Tamsulosin $\mathrm{HCl}$ & $\begin{array}{l}\text { Benign prostatic } \\
\text { hyperplasia }\end{array}$ & Astellas Pharma Inc. & \\
\hline Irribow $^{\circledR}$ OD & Ramosetron $\mathrm{HCl}$ & Irritable bowel syndrome & Astellas Pharma Inc. & \\
\hline Nasea ${ }^{\circledR}$ OD & Ramosetoron $\mathrm{HCl}$ & Anti-emetic & Yamanouchi & \\
\hline Vesicare $^{\circledR}$ OD & Solifenacin succinate & Overactive bladder & Astellas Pharma Inc. & \\
\hline Calpol ${ }^{\circledR}$ Six Plus Fastmelts & Paracetamol & Analgesic, anti-pyretic & McNeil Products Ltd & Flashtab $^{\circledR}$ \\
\hline Dolflash $^{\circledR}$ & Acetaminophen & Analgesic, anti-pyretic & Sanofi-Aventis & \\
\hline Excedrin Quicktabs & Acetaminophen, Caffeine & Analgesic, anti-pyretic & Bristol-Myers Squibb & \\
\hline Nurofen ${ }^{\circledR}$ Flashtab & Ibuprofen & Analgesic, anti-pyretic & Boots Healthcare & \\
\hline Ondansetron Flashtab ${ }^{\circledR}$ & Ondansetron & Anti-emetic & Teva & \\
\hline OxynormOro ${ }^{\circledR}$ & Oxycodone chlorhydrate & Cancer related pain & Mundipharma & \\
\hline Paracetamol Flashtab ${ }^{\circledR}$ & Paracetamol & Analgesic, anti-pyretic & Ranbaxy & \\
\hline
\end{tabular}




\begin{tabular}{|c|c|c|c|c|}
\hline $\begin{array}{l}\text { Prevacid }{ }^{\circledR} \text { SoluTab } \\
\text { (Delayed release ODT) }\end{array}$ & Lansoprazole & $\begin{array}{l}\text { Gastroesophageal reflux } \\
\text { disease }\end{array}$ & Takeda & \\
\hline Solupred Orodispersible Tablet & Prednisolone & Asthma & Sanofi-Aventis & \\
\hline Tachipirina Flashtab ${ }^{\circledR}$ & Paracetamol & Analgesic, anti-pyretic & Angelini & \\
\hline Tramalene $^{\circledR}$ Flashtab $^{\circledR}$ & Tramadol $\mathrm{HCl}$ & Potent analgesic & Ethypharm & \\
\hline $\operatorname{Trambax}^{\circledR}$ MD & Tramadol $\mathrm{HCl}$ & Potent analgesic & Ranbaxy & \\
\hline Zamadol ${ }^{\circledR}$ Melt & Tramadol $\mathrm{HCl}$ & Potent analgesic & MEDA Pharma & \\
\hline Citalopram ${ }^{\circledR}$ ODT & Citalopram hydrobromide & Anti-depressant & Biovail & FlashDose ${ }^{\circledR}$ \\
\hline Fluoxetine ${ }^{\circledR}$ ODT & Fluoxetine & Anti-depressant & Biovail & \\
\hline Ralivia FlashDose ${ }^{\circledR}$ & Tramadol $\mathrm{HCl}$ & Potent analgesic & Biovail & \\
\hline Tovalt $^{\mathrm{TM}}$ ODT & Zolpidem tartrate & Insomnia & Biovail & \\
\hline Lamictal ${ }^{\circledR}$ ODT & Lamotrigine & Bipolar disorders & GlaxoSmithKline & AdvaTab $^{\circledR}$ \\
\hline Unisom ${ }^{\circledR}$ SleepMelt & Diphenhydramine $\mathrm{HCl}$ & Anti-histaminic & Chattem, Inc. & \\
\hline Caffe Magia ${ }^{\circledR}$ & Vitamin B and Caffeine & Stimulant & Akina & Frosta $^{\circledR}$ \\
\hline Ceto- $Q^{\circledR}$ & $\begin{array}{l}\text { Mannitol, Calcium carbonate, } \\
\text { Xylitol, Yucca extract }\end{array}$ & Toothpaste tablet & Akina & \\
\hline Hyoscyamine Sulfate ODT & Hyoscyamine sulfate & Anti-ulcer & Perrigo & OraQuick ${ }^{\circledR}$ \\
\hline
\end{tabular}

\section{Characterizations of oral disintegrating tablets}

$\begin{aligned} & \text { Evaluation of powders or granules (pre-compression } \\ & \text { parameters evaluation) }\end{aligned}$
(n)

\section{Bulk and tapped density}

Ten gm of a dry powder or granular sample is placed in a $100 \mathrm{ml}$ graduated cylinder. The volume occupied by the powder or granules is measured and the bulk density is calculated using equation 3 . Tapped density is determined by a tapped density tester. The volume occupied by the powder or granules after tapping is used to calculate the tapped density using equation $4[40,100]$.

$$
\text { Bulk density }=\frac{\text { woight of the powder }}{\text { buk volume of tha powder (Eq.3) }}
$$

\section{Tupped dersily $-\frac{\text { Weight of the bulk sample }}{\text { bull ao hime of the bulk asmplo en Eapping }}$ (Eq. 4)} Hausner ratio and carr's compressibility index

Hausner ratio and carr's compressibility index are calculated based on bulk and tapped density results using equations 5 and 6, respectively.

$$
\begin{aligned}
\text { Hausner ratio } & =\frac{\text { topped density }}{\text { buk density }} \text { (Eq. 5) } \\
\text { Caxr's rmmpressihility index }(\%) & =\frac{\text { tapped density-bulk density }}{\text { tapped density }} \times 1 \mathrm{CO}
\end{aligned}
$$

Flowability is determined based on the results of hausner ratio and carr's compressibility index as shown in table 6.

Table 6: Specification for hausner ratio and carr's compressibility index

\begin{tabular}{lll}
\hline Hausner ratio & Carr's compressibility index (\%) & Flowability \\
\hline $1.00-1.11$ & $0-10$ & Excellent \\
$1.12-1.18$ & $11-15$ & Good \\
$1.19-1.25$ & $16-20$ & Fair \\
$1.26-1.34$ & $21-25$ & Passable \\
$1.35-1.45$ & $26-31$ & Poor \\
$1.46-1.59$ & $32-37$ & Very poor \\
$>1.60$ & $>38$ & Very, very poor \\
\hline
\end{tabular}

Table 7: Specification of angle of repose $(\theta)$

\begin{tabular}{ll}
\hline Angle of repose (degree) & Flowability \\
\hline $25-30$ & Excellent \\
$31-35$ & Good \\
$36-40$ & Fair \\
$40-45$ & Passable \\
$46-55$ & Poor \\
$56-65$ & Very poor \\
$>66$ & Excellent \\
\hline
\end{tabular}

\section{Angle of repose $(\theta)$}

Angle of repose $(\theta)$ is determined by the fixed funnel and freestanding cone method. The method employed a funnel that is fixed at a certain height $(\mathrm{h})$ on a graph paper placed on a flat horizontal surface. The powder or granules sample is carefully passed through the funnel till the apex at the conical pile touched the tip of the funnel. Thus, with (r) being the radius of the base of the conical pile as shown in equation 7 [101].

$$
\operatorname{Tan} \theta=\frac{\hbar}{r} \text { (Eq. 7) }
$$

Where, (h) and (r) are the height and radius of the base of the conical pile
Flowability is determined based on the results of angle of repose as shown in table 7.

\section{Porosity $(\varepsilon)$}

Porosity $(\varepsilon)$ is calculated from apparent density ( $\rho a p p)$ and true density ( $\rho$ true) as in equation 8 [40].

$$
c-\left\lfloor 1-\left(\frac{\text { papp }}{\text { ptrue }}\right)\right\rfloor \times 100
$$

The true density ( $\rho$ true), which is the density of the particles that make up a powder or particulate solid, is measured by gas displacement using a pycnometer [102]. 


\section{Evaluation of tablets (post-compression parameters evaluation)}

\section{(1) Weight uniformity or $\%$ of weight variation}

Twenty tablets were randomly selected from the production batch and weighted individually to check their weight uniformity. The percentage of weight variation is calculated using equation 9 [40, 103].

$$
\% \text { of weight variation }=\frac{\text { (individuel weight }- \text { awrage weight) }}{\text { madvidual welght }} \times 100 \text { (Eq. 9) }
$$

The percentage of tablet weight deviation is shown in table 8 .

Table 8: Uniformity of weight of tablets

\begin{tabular}{ll}
\hline Average tablet weight (mg) & \% Deviation \\
\hline Less than $80 \mathrm{mg}$ & \pm 10 \\
More than $80 \mathrm{mg}$ but less than $250 \mathrm{mg}$ & \pm 7.5 \\
$250 \mathrm{mg}$ and more & \pm 5 \\
\hline
\end{tabular}

\section{Tablet hardness}

Tablet hardness is measured by the hardness tester in newton $(\mathrm{N})$ or kilopond ( $\mathrm{kP}$ ) per unit tablet. Each tablet is placed individually in the hardness tester and the crushing load is measured. In general, the hardness of ODTs is set to be lower than conventional tablets because of increasing hardness results in decreasing tablet disintegration rate $[40,103]$.

\section{Tablet friability}

Twenty tablets are accurately weighted and placed in the friabilator chamber, then allowed to rotate at $25 \mathrm{rpm}$ for $4 \mathrm{~min}$. Tablets are collected and reweighted. The percentage of weight loss in tablet is calculated using equation 10 and taken as a measure of friability. Tablets pass the friability test if not more than $1 \%$ of the tablets weight was lost $[40,103]$.

$$
\% \text { Friability }=\frac{(W 0-W f)}{W_{0}} \times 100
$$

$\mathrm{W}_{0}$ : initial weight of tablets

\section{$\mathrm{W}_{\mathrm{f}}$ final weight of tablets}

\section{Tablet thickness and diameter}

Tablet thickness and diameter are measured by using a micrometer caliper in millimeter ( $\mathrm{mm}$ ) per unit tablet [40].

\section{Uniformity of dispersion}

Twenty tablets are placed in a beaker containing $100 \mathrm{ml}$ of purified water and stirred gently for $2 \mathrm{~min}$. The dispersion is allowed to pass through 22 mesh screen. Tablets would pass the test if no residue remained on the screen [104].

\section{Water absorption ratio}

A small piece of tissue paper folded twice is placed in a small petridish containing $6 \mathrm{ml}$ of purified water. A tablet is placed onto the tissue paper and the time required for completely wetted is measured. The wetted tablet is then re-weighed. Water absorption ratio $(\mathrm{R})$ is calculated by using equation 11 [104].

$$
R=\frac{\left(W_{x}-W_{L}\right)}{W_{b}} \times 100 \text { (Eq. 11) }
$$

$\mathrm{W}_{\mathrm{b}}$ : is the weight of tablet before water absorption

$\mathrm{W}_{\mathrm{a}}$ : is the weight of tablet after water absorption

\section{Wetting time}

Five circular tissue papers of $10 \mathrm{~cm}$ diameter are placed in a petridish with a $10 \mathrm{~cm}$ diameter. Ten millimeters of water containing Eosin, a water-soluble dye, is added to petridish. A tablet is carefully placed on the surface of the tissue paper. The time required for water to reach upper surface of the tablet is noted as a wetting time $[50,101]$.

\section{In-vitro disintegration time}

Disintegration time is evaluated using the disintegration tester without disk. The disintegration medium is usually $900 \mathrm{ml}$ of purified water kept at $37 \pm 0.5{ }^{\circ} \mathrm{C}$. The time required for complete disintegration is in seconds $[40,103]$.

\section{In-vitro and comparative dissolution}

Four dissolution medias are commonly used for evaluating in vitro and comparative dissolution, namely $0.1 \mathrm{~N} \mathrm{HCl}(\mathrm{pH} \mathrm{1.2)}$, acetate buffer ( $\mathrm{pH}$ 4.5), phosphate buffer $(\mathrm{pH}$ 6.8) and artificial saliva solution $(\mathrm{pH}$ 7.0). Dissolution tester is used for experimental evaluation following the USP paddle (most common). All dissolution tests are usually conducted in $900 \mathrm{ml}$ of each dissolution media maintained at a constant temperature of $37{ }^{\circ} \mathrm{C} \pm 0.5{ }^{\circ} \mathrm{C}$ with paddle rotation speed of $25,50,75$ or $100 \mathrm{rpm}$. Comparative dissolution studies is mainly conducted against the reference marketed product. Dissolution profiles are compared with the reference marketed product using the similarity factor (f2) defined by the following equation $12[40,103]$.

$$
f_{2}=50 \operatorname{lng}\left\{\left[1+\frac{1}{n} \sum_{n=1}^{n}\left(R_{6}-T_{v}\right)^{2}\right]^{-0.5} \times 100\right\}
$$

Where $(n)$ is the number of sampling time points, $\left(\mathrm{R}_{t}\right)$ and $\left(\mathrm{T}_{t}\right)$ are the mean percent dissolved of the reference product and the prepared ODTs respectively, up to each time point $(t),\left(f_{2}\right)$ represents a logarithmic transformation of the sum-squared error of difference between the reference and the test products over all time points. In order to consider similar dissolution profiles, $\left(\mathrm{f}_{2}\right)$ values should be higher than 50 .

\section{Novel formulations of oral disintegrating tablets}

Many reported applications of ODTs have been described in the literature. Agiba et al. [40] incorporated a high dose of nutraceuticals glucosamine sulphate (GluS) and chondroitin sulphate (CS) into ODTs in order to improve their disintegration, dissolution and subsequent their bioavailability. GluS/CS ODTs were prepared by direct compression and melt-granulation techniques, using a blend of conventional and coprocessed multifunctional excipients as Pharmaburst ${ }^{\mathrm{TM}} \mathrm{C} 1$. Pharmaburst ${ }^{\mathrm{TM}} \mathrm{C} 1$ turned out to be the key excipient in improving the tablet characteristics, disintegration and dissolution profile. Kumar and Saharan [101] developed ODTs of salbutamol sulphate, using a combination of three different superdisinetgrants in different ratios. They concluded that the binary combination of superdisintegrants was more effective in disintegration and dissolution than the individual use of one superdisintegrant. Dave et al. [105] developed ODTs of chlorpheniramine maleate based on lyophilization technique, using superdisinetgrants as croscarmellose sodium and crospovidone for faster disintegration and dissolution. Türkmen et al. [106] developed fexofenadine hydrochloride ODTs by direct compression using high functionality excipients as F-Melt ${ }^{\circledR}$, Pearlitol ${ }^{\circledR}$ Flash, Pharmaburst ${ }^{\circledR}$ 500, Prosolv ${ }^{\circledR}$ Easytab SP, Ludiflash ${ }^{\circledR}$ and Parteck ${ }^{\circledR}$ ODT. ODTs formulated with Pharmaburst ${ }^{\circledR} 500$ were the most promising formulation with respect to physical characteristics and dissolution rate. Shoormeij et al. [107] developed meloxicam ODTs using solid dispersions followed by direct compression. Meloxicam solid dispersions were prepared by the melting method, using poloxamer 188 as a hydrophilic carrier and crospovidone as a superdisintegrant. Moqbel et al. [108] developed ODTs of 
chlorzoxazone using two different approaches; co-processed excipients or liquisolid technique. F-melt ${ }^{\circledR}$, Pearlitol ${ }^{\circledR}$ flash, Pharmaburst ${ }^{\circledR}$ 500, Prosolv ${ }^{\circledR}$ ODT and Starlac ${ }^{\circledR}$ were used as coprocessed multifunctional excipients, whereas in liquisolid method, Avicel ${ }^{\circledR}$ PH101, Cellactose ${ }^{\circledR} 80$ and Microcelac ${ }^{\circledR} 100$ were used as carriers, while Aerosil ${ }^{\circledR} 200$ was a coating material. Both approaches were capable of producing ODTs with ease and low cost of manufacture. ODTs formulated with Pharmaburst ${ }^{\circledR} 500$ showed the best results in terms of palatability, mechanical strength, disintegration and dissolution. Ibrahim and El Sayeh [109] formulated orally disintegrating tablets containing furosemide; a potent diuretic used mainly in the management of hypertension. ODTs were prepared by direct compression method for tastemasking purposes. Nishiyama et al. [110] prepared taste-masking granules of lafutidine for ODTs using water-insoluble/water-soluble polymers combinations. Lafutidine taste-masking granules were prepared by coating lafutidine granules with a taste-masking layer prepared by combining ethylcellulose (water-insoluble polymer) and hypromellose (water-soluble polymer), and ODTs were prepared by direct compression method using mannitol as a diluent, low-substituted hydroxypropyl cellulose as a disintegrant and sodium stearyl fumarate as a water-soluble lubricant. Desai et al. [111] developed $\beta$-cyclodextrin ( $\beta$-CD) solid dispersion-based ODTs of eslicarbazepine acetate (ESL), for improving the dissolution and providing rapid anti-epileptic action. ESL- $\beta$-CD solid dispersion was prepared by solvent evaporation method and then compressed into ODTs by direct compression, using superdisintegrants as crosspovidone, sodium starch glycolate, pregelatinzed starch and croscarmellose. Microcrystalline cellulose was further added to aid in tabletting. Yıldız et al. [112] developed new ODTs containing mirtazapine; an antidepressant drug molecule having bitter taste by coacervation followed by direct compression using different fillers (Ludiflash $^{\circledR}$, Phamaburst ${ }^{\mathrm{TM}}$ C1, Galen ${ }^{\circledR}$ IQ, F-Melt ${ }^{\circledR}$ and Mannitol Parteck ${ }^{\circledR}$ M100), disintegrants (Kollidon ${ }^{\circledR}$ CL, Ac-Di-Sol ${ }^{\circledR}$, Explotab ${ }^{\circledR}$ and Kollidon ${ }^{\circledR}$ CL/Amberlit ${ }^{\circledR}$ IRP-88 mixture), glidant (Aerosil ${ }^{\circledR} 200$ ), citric acid and sodium carbonate (effervescent mixture). Chen et al. [113] prepared montelukast sodium ODTs with a similar dissolution profile as the marketed product, Romilast ${ }^{\circledR}$ ODTs (Ranbaxy). Montelukast sodium ODTs were prepared by direct compression and wet-granulation methods, using a variety of excipients such as microcrystalline cellulose (M105 and M301), mannitol (SD200 and 160C), croscarmellose soldium, hydroxypropyl cellulose, and magnesium stearate. The prepared ODTs showed equivalent dissolution profiles to the marketed product in four different media. El-Maghraby and El-Sergany [114] enhanced the intra-oral administration of nisoldipine used in the treatment of angina pectoris and hypertension by its formulation in ODTs with subsequent fast dissolution. Nisoldipine ODTs were formulated by solid dispersion technique by using solvent evaporation method. Cantor et al. [115] described a novel formulation approach for tastemasking drugs with poor organoleptic properties such as clindamycin hydrochloride. Taste-masked ODTs of clindamycin hydrochloride were prepared by its coating with microcrystalline cellulose beads followed by the addition of a taste-masking layer of amino methacrylate copolymer coating suspension.

\section{Future prospects and possible challenges in the development of oral disintegrating tablets}

Despite the advances in ODT technologies, formulation of hydrophobic drugs with poor bioavailability is still a big challenge, particularly at high doses. The need of a new technology to incorporate higher doses of hydrophobic drugs without affecting the mechanical and disintegrating properties is crucial. The disintegration times of most marketed ODTs are acceptable (within $3 \mathrm{~min}$ as stated by European Pharmacopeia), but certainly further improvement would be an advantage. Generally, the disintegration time is affected by many formulation variables, therefore, a balance between the disintegration time and other tablet properties as mechanical strength, friability, thickness and diameter should be well-considered. Development of cheap and effective direct tastemasking methods would also be advantageous. On the other hand, the development of ODTs usually requires large amounts of excipients and having large drug doses will make the final dosage form very large. Therefore, the formulation of ODTs containing high doses drugs is still a problematic issue and need further new and advanced technologies.

\section{CONCLUSION}

The popularity of ODTs has increased dramatically over the last few decades. There are many globally marketed products that have been formulated into ODT dosage forms. The most important parameters in ODT formulations are rapid onset of action, very fast drug release, quick disintegration and dissolution, and these could be achieved by formulating tablets with high porous structures or by adding a blend of disintegrants, superdisintegrants, effervescent systems, and/or coprocessed multifunctional excipients. ODTs prepared by direct compression technique usually have good mechanical properties but could be further improved by using high functionality excipients. Considering many advantages and benefits of ODT systems, it is only a matter of time till the majority of oral solid dosage forms become ODT formulations.

\section{ACKNOWLEDGEMENT}

The authors would like to thank Dr Sherif Lashin, R\&D Director, Dr Abla Abdel Aziz, R\&D Senior Manager, SIGMA Pharmaceutical Industries; Dr Wageeh Abdel Hakeem, R\&D Deputy Manager, October Pharma; Dr Maha Nasr, Associate Professor of Pharmaceutics and Industrial Pharmacy, Ain Shams University in Cairo and Mutah University in Jordan; and Dr Hanan Refai, Professor of Pharmaceutics and Industrial Pharmacy, Cairo University and Misr University for Science and Technology in Egypt for their fruitful discussions on the theme of the review article.

\section{AUTHORS CONTRIBUTIONS}

All the authors have contributed equally.

\section{CONFLICT OF INTERESTS}

The authors report no conflicts of interest

\section{REFERENCES}

1. Pather SI, Rathbone MJ, Senel S. Oral transmucosal drug delivery. Drug Pharm Sci 2008;183:53.

2. Rathbone MJ, Drummond BK, Tucker IG. The oral cavity as a site for systemic drug delivery. Adv Drug Delivery Rev 1994;13:1-22.

3. Rathbone MJ, Senel S, Pather I. Oral mucosal drug delivery and therapy. Springer 2015. Doi:10.1007/978-1-4899-7558-4

4. Squier CA, Wertz PW. Structure and function of the oral mucosa and implications for drug delivery. Drugs Pharm Sci 1996;74:1-26.

5. Şenel S, Hıncal AA. Drug permeation enhancement via buccal route: possibilities and limitations. J Controlled Release 2001;72:133-44.

6. Collins L, Dawes C. The surface area of the adult human mouth and thickness of the salivary film covering the teeth and oral mucosa. J Dent Res 1987;66:1300-2.

7. Zhang $\mathrm{H}$, Zhang J, Streisand JB. Oral mucosal drug delivery. Clin Pharmacokinet 2002;41:661-80.

8. Avery Smith W, Dellarosa DM. Approaches to treating dysphagia in patients with brain injury. Am J Occup Ther 1994;48:235-9.

9. Sastry SV, Nyshadham JR, Fix JA. Recent technological advances in oral drug delivery-a review. Pharm Sci Tech Today 2000;3:138-45.

10. Porter SC. Novel drug delivery: review of recent trends with oral solid dosage forms. Am Pharm Rev 2001;4:28-36.

11. Bhandari S, Mittapalli RK, Gannu R, Rao YM. Orodispersible tablets: an overview. Asian J Pharm 2008;2:2-11.

12. Wilson C, Washington N, Peach J, Murray G, Kennerley J. The behaviour of a fast-dissolving dosage form (Expidet) followed by $\gamma$-scintigraphy. Int J Pharm 1987;40:119-23.

13. Brown D. Orally disintegrating tablets-taste over speed. Drug Delivery Technol 2003;3:58-61.

14. Fu Y, Yang S, Jeong SH, Kimura S, Park K. Orally fast disintegrating tablets: developments, technologies, tastemasking and clinical studies. Crit Rev Ther Drug Carrier Sys 2004;21:433-76.

15. Bradoo R, Shahani S, Poojary S, Deewan B, Sudarshan S. Fast dissolving drug delivery systems. Jama India 2001;4:27-31. 
16. Ghosh T, Ghosh A, Prasad D. A review on new generation orodispersible tablets and its future prospective. Int J Pharm Pharm Sci 2011;3:1-7.

17. Dobetti L. Fast-melting tablets: developments and technologies. Pharm Tech 2001;12:44.

18. Reddy L, Ghosh B. Fast dissolving drug delivery systems: a review of the literature. Indian J Pharm Sci 2002;64:331.

19. Aurora J, Pathak V. Oral disintegrating technologies: Oral disintegrating dosage forms: an overview. Drug Delivery Technol 2005;5:50-4.

20. Sugihara M, Hidaka M, Saitou A. Discriminatory features of dosage form and package. Japan J Hosp Pharm 1986;12:322-8.

21. Habib W, Khankari R, Hontz J. Fast-dissolve drug delivery systems. Crit Rev Ther Drug Carrier Sys 2000;17:61-72.

22. Seager H. Drug-delivery products and the Zydis fast-dissolving dosage form. J Pharm Pharmacol 1998;50:375-82.

23. Iles MC, Atherton AD, Copping NM. Freeze-dried dosage forms and methods for preparing the same. US Patent 5188825A; 1993.

24. O'Connor RE, Schwartz JB. Extrusion and spheronization technology. Pharm Pelletization Tech 1989;37:116-20.

25. Agarwal V, Kothari B, Moe D, Khankari R. Drug delivery: fastdissolve systems. Encyclopedia Pharm Tech 2006;2:1104-14.

26. Fini A, Bergamante V, Ceschel GC, Ronchi C, de Moraes CAF. Fast dispersible/slow releasing ibuprofen tablets. Eur J Pharm Pharm 2008;69:335-41.

27. Masters K. Part I-basic principles, definitions- $\S 1$ spray drying fundamentals: process stages. Spray Drying Handbook. $5^{\text {th }}$ edition. Longman Scientific and Technical and John Wiley and Sons, Inc; 1991. p. 32-3.

28. Prasad N, Straus D, Reichart G. Cyclodextrin flavor delivery systems. US Patent 6287603B1; 2001.

29. Venkatesh D. Formulation of taste masked oro-dispersible tablets of ambroxol hydrochloride. Diss 2005. Doi:10.4103/0973-8398.45043

30. Hughes L. Selecting the right ion exchange resin. Pharma Quality 2005;1:54-6.

31. Jeong SH, Park K. Development of sustained release fastdisintegrating tablets using various polymer-coated ionexchange resin complexes. Int J Pharm 2008;353:195-204.

32. Lachman L, Lieberman HA, Kanig JL. The theory and practice of industrial pharmacy. Lea and Febiger Philadelphia; 1976.

33. Bangale GS, Shinde G, Rathinaraj BS. New generation of orodispersible tablets: recent advances and future propects. Int J Adv Pharm Sci 2011;2:52-62.

34. Nail SL, Gatlin LA. Freeze-drying: principles and practice. In: Pharmaceutical Dosage Forms-Parenteral Medications, CRC Press; 2016. p. 366-94.

35. Chaudhari SP, Kotian NR, Bhadgale MM, Bafna VC. Formulation development and evaluation of orally disintegrating tablets of doxazosin mesylate. Asian J Pharm 2012;266-74. Doi:10.4103/0973-8398.107562

36. Wagh VD, Ghadlinge SV. Taste masking methods and techniques in oral pharmaceuticals: current perspectives. J Pharm Res 2009;2:1049-54.

37. Van Scoik KG. Solid pharmaceutical dosage in tablet triturate form and method of producing same. US Patent 5082667A; 1992.

38. Pebley WS, Jager NE, Thompson SJ. Rapidly distintegrating tablet. US Patent 5298261; 1994.

39. Kuno Y, Kojima M, Ando S, Nakagami H. Effect of preparation method on properties of orally disintegrating tablets made by phase transition. Int J Pharm 2008;355:87-92.

40. Agiba AM, Abdel Hamid S, Nasr M, Geneidi AS. Geriatric oriented high dose nutraceutical ODTs: formulation and physicomechanical characterization. Curr Drug Delivery 2018;15:267-77.

41. Abdelbary G, Prinderre P, Eouani C, Joachim J, Reynier J, Piccerelle $P$. The preparation of orally disintegrating tablets using a hydrophilic waxy binder. Int J Pharm 2004;278:423-33.

42. Perissutti B, Rubessa F, Moneghini M, Voinovich D. Formulation design of carbamazepine fast-release tablets prepared by melt granulation technique. Int J Pharm 2003;256:53-63.

43. Koizumi K, Watanabe Y, Morita K, Utoguchi N, Matsumoto M. New method of preparing high-porosity rapidly saliva soluble compressed tablets using mannitol with camphor, a subliming material. Int J Pharm 1997;152:127-31.

44. Makino T, Yamada M, Kikuta J. Fast dissolving tablet and its production. US Patent 5720974; 1998.

45. Shyamala B, Narmada G. Rapid dissolving tablets: a novel dosage form. Indian Pharm 2002;13:9-12.

46. Chivers T. Process for making candy floss. US Patent 3723134A; 1973.

47. Chiver TE, Minn O. Process for making candy floss. US Patent 730057; 2003.

48. Shukla D, Chakraborty S, Singh S, Mishra B. Mouth dissolving tablets II: An overview of evaluation techniques. Sci Pharm 2009;77:327-42.

49. Cousin G, Bruna E, Gendrot E. Rapidly disintegratable multiparticular tablet. US Patent 5464632A; 1995.

50. Bi Y, Sunada H, Yonezawa Y, Danjo K, Otsuka A, IIDA K. Preparation and evaluation of a compressed tablet rapidly disintegrating in the oral cavity. Chem Pharm Bull 1996;44:2121-7.

51. Gilis PMV, De Conde VFV. Fast-dissolving galanthamine hydrobromide tablet. US Patent 6099863A; 2000.

52. Gattani S, Shiyani B, Kakade K, Patil A, Surana S. Formulation and development of mouth dissolving tablet of ondensetron hydrochloride by using superdisintegrants. Indian Drugs 2009;46:44-50.

53. Wagh MA, Kothawade DP, Salunkhe KS, Chavan NV, Daga VR. Techniques used in orally disintegrating drug delivery system. Int J Drug Delivery 2010;2. Doi:10.5138/ijdd.2010.0975.0215.02018

54. Allen LV, Wang B. Process for making a particulate support matrix for making a rapidly dissolving dosage form. US Patent 5587180A; 2001.

55. Heinemann H, Rothe W. Preparation of porous tablets. US Patent 3885026; 1975.

56. Roser BJ, Blair J. Rapidly soluble oral solid dosage forms, methods of making same, and compositions thereof. US Patent 5762961; 1998.

57. Lo JB. Method of producing porous delivery devices. WO Patent 9318757; 1993.

58. Rowe RC, Sheskey PJ, Owen SC. Handbook of pharmaceutical excipients. Pharmaceutical Press London; 2009. p. 9.

59. Shangraw R, Wallace JW, Bowers F. Morphology and functionality in tablet excipients for direct compression. Pharm Technol 1987;11:136-43.

60. Kitamori N, Makino T. Mprovement in pressure-dependent dissolution of trepibutone tablets by using intragranular disintegrants. Drug Dev Indian Pharm 1982;8:125-39.

61. Kottke M, Chueh HR, Rhodes C. Comparison of disintegrant and binder activity of three corn starch products. Drug Dev Ind Pharm 1992;18:2207-23.

62. Small L, Augsburger L. Aspects of the lubrication requirements for an automatic capsule filling machine. Drug Dev Ind Pharm 1978;4:345-72.

63. Mattsson S, Nyström C. Evaluation of critical binder properties affecting the compactibility of binary mixtures Drug Dev Ind Pharm 2001;27:181-94.

64. Rudnic E, Rhodes C, Welch S, Bernardo P. Evaluations of the mechanism of disintegrant action. Drug Dev Ind Pharm 1982;8:87-109.

65. Khan K, Rhodes C. Water sorption properties of tablet disintegrants. J Pharm Sci 1975;64:447-51.

66. Wan LS, Prasad KP. Uptake of water by excipients in tablets. Int J Pharm 1989;50:147-53.

67. Thibert R, Hancock BC. Direct visualization of superdisintegrant hydration using environmental scanning electron microscopy. J Pharm Sci 1996;85:1255-8.

68. Gordon MS, Chowhan ZT. Effect of tablet solubility and hygroscopicity on disintegrant efficiency in direct compression tablets in terms of dissolution. J Pharm Sci 1987;76:907-9.

69. Gebre Mariam T, Winnemöller M, Schmidt PC. An evaluation of the disintegration efficiency of a sodium starch glycolate prepared from enset starch in compressed tablets. Eur J Pharm Pharm 1996;42:124-32. 
70. Gordon MS, Rudraraju VS, Dani K, Chowhan ZT. Effect of the mode of super disintegrant incorporation on dissolution in wet granulated tablets. J Pharm Sci 1993;82:220-6.

71. Khattab I, Menon A, Sakr A. Effect of mode of incorporation of disintegrants on the characteristics of fluid-bed wet-granulated tablets. J Pharm Pharmacol 1993;45:687-91.

72. Kleinebudde P. Application of low substituted hydroxypropylcellulose (L-HPC) in the production of pellets using extrusion/spheronization. Int J Pharm 1993;96:119-28.

73. Schiermeier S, Schmidt PC. Fast dispersible ibuprofen tablets. Eur J Pharm Sci 2002;15:295-305.

74. Palmieri A. Polacrilin potassium. Handbook of Pharmaceutical Excipients; 2012;7:571-2.

75. Bele $\mathrm{MH}$, Derle DV. Mechanism of disintegrant action of polacrilin potassium: Swelling or wicking? Acta Pharm Sinica B 2012;2:70-6.

76. Quodbach J, Kleinebudde P. Systematic classification of tablet disintegrants by water uptake and force development kinetics. J Pharm Pharmacol 2014;66:1429-38.

77. Desai PM, Liew CV, Heng PWS. Review of disintegrants and the disintegration phenomena. J Pharm Sci 2016;105:2545-55.

78. Quodbach J, Moussavi A, Tammer R, Frahm J, Kleinebudde P. Tablet disintegration studied by high-resolution real-time magnetic resonance imaging. J Pharm Sci 2014;103:249-55.

79. Moreton RC. Disintegrants in tableting. In: Pharmaceutical Dosage Forms-Tablets, CRC Press; 2008. p. 233-66.

80. Colombo P, Conte U, Caramella C, Geddo M, La Manna A. Disintegrating force as a new formulation parameter. J Pharm Sci 1984;73:701-5.

81. De Schoenmaker B, Van der Schueren L, De Vrieze S, Westbroek $\mathrm{P}$, De Clerck K. Wicking properties of various polyamide nanofibrous structures with an optimized method. J Appl Polym Sci 2011;120:305-10.

82. Kissa E. Wetting and wicking. Text Res J 1996;66:660-8.

83. Bolhuis G, Lerk C, Lie-A-Huen L. The role of water uptake on tablet disintegration. Design of an improved method for penetration measurements. Pharm Acta Helv 1986;61:22-9.

84. Patel S, Kaushal AM, Bansal AK. Effect of particle size and compression force on compaction behavior and derived mathematical parameters of compressibility. Pharm Res 2007;24:111-24.

85. Karehill P, Nyström C. Studies on direct compression of tablets XXI. Investigation of bonding mechanisms of some directly compressed materials by strength characterization in media with different dielectric constants (relative permittivity). Int J Pharm 1990;61:251-60.

86. Ferrari F, Bertoni M, Bonferoni M, Rossi S, Caramella C, Nyström C. Investigation on bonding and disintegration properties of pharmaceutical materials. Int J Pharm 1996;136;71-9.

87. Luangtana Anan M, Catellani P, Colombo P, Dinarvand R, Fell J, Santi P. The role of bond weakening by liquids in the disintegration of tablets. Eur J Pharm Biopharm 1992;38:169-71.

88. Lowenthal W. Mechanism of action of tablet disintegrants. Pharm Acta Helv 1973;48:589-609.

89. Caramella C, Ferrari F, Conte U, Gazzaniga A, La Manna A, Colombo P. Experimental evidence of disintegration mechanisms. Acta Pharm Technol 1989;35:30-3.

90. Kanojia N, Kaur L, Nagpal M, Bala R. Modified excipients in novel drug delivery: need of the day. J Pharm Tech Res Mang 2014;1:81-107.

91. Desai U, Chavan R, Mhatre P, Chinchole R. A review: coprocessed excipients. Int J Pharm Sci Rev Res 2012;12:93-105.

92. Lafon L. Galenic form for oral administration and its method of preparation by lyophilization of an oil-in-water emulsion. Patent EP0159237A1; 1986.

93. Mizumoto T, Masuda Y, Kajiyama A, Yanagisawa M, Nyshadham JR. Tablets quickly disintegrating in the oral cavity and process for producing the same. US Patent 6589554B1; 2003.
94. Mizumoto T, Masuda Y, Fukui M. Intrabuccally dissolving compressed moldings and production process thereof. US Patent 5576014A; 1996.

95. Wehling F, Schuehle S. Base coated acid particles and effervescent formulation incorporating same. US Patents 5503846A; 1996.

96. Wehling F, Schuehle S, Madamala N. Effervescent dosage form with microparticles. US Patent 5178878A; 1993.

97. Ohta M, Hayakawa E, Ito K, Tokuno S, Morimoto K, Watanabe Y. Intrabuccally rapidly disintegrating tablet. US Patent 20010014340A1; 2001.

98. Myers GL, Battist GE, Fuisz RC. Process and apparatus for making rapidly dissolving dosage units and product therefrom. US Patent 5851553A; 1999.

99. Kaushik D, Dureja H, Saini T. Orally disintegrating tablets: An overview of melt-in mouth tablet technologies and techniques. Tablets Capsules 2004;2:30-6.

100. US Pharmacopeia. Bulk Density and Tapped Density of Powders; 2015. p. 616.

101. Kumar A, Saharan VA. A comparative study of different proportions of superdisintegrants: formulation and evaluation of orally disintegrating tablets of salbutamol sulphate. Turk J Pharm Sci 2017;14:40-8.

102. Nordström J, Persson A, Lazorova L, Frenning G, Alderborn G. The degree of compression of spherical granular solids controls the evolution of microstructure and bond probability during compaction. Int J Pharm 2013;442:3-12.

103. European pharmacopoeia, Strasbourg, France. The directorate for the quality of medicines of the council of Europe 9EDQM; 2002.

104. Arora P, Sethi VA. Orodispersible tablets: a comprehensive review. Int J Res Dev Pharm Life Sci 2013;2:270-84.

105. Dave V, Yadav RB, Ahuja R, Yadav S. Formulation design and optimization of novel fast dissolving tablet of chlorpheniramine maleate by using lyophilization techniques. Bull Faculty Pharm Cairo University 2017;55:31-9.

106. Türkmen O, Şenyigit ZA, Baloglu E. Formulation and evaluation of fexofenadine hydrochloride orally disintegrating tablets for pediatric use. J Drug Delivery Sci Tech 2018;43:201-10.

107. Shoormeij Z, Taheri A, Homayouni A. Preparation and physicochemical characterization of meloxicam orally fast disintegration tablet using its solid dispersion. Braz J Pharm Sci 2017;53. Doi.org/10.1590/s2175-97902017000400176

108. Moqbel HA, El Meshad AN, El Nabarawi MA. Comparative study of different approaches for preparation of chlorzoxazone orodispersible tablets. Drug Dev Ind Pharm 2017;43:742-50.

109. Ibrahim MA, Amal El Sayeh F. Optimized furosemide taste masked orally disintegrating tablets. Saudi Pharm J 2017;25:1055-62.

110. Nishiyama T, Ogata T, Ozeki T. Preparation of bitter tastemasking granules of lafutidine for orally disintegrating tablets using water-insoluble/soluble polymer combinations. J Drug Delivery Sci Tech 2016;32:38-42.

111. Desai S, Poddar A, Sawant K. Formulation of cyclodextrin inclusion complex-based orally disintegrating tablet of eslicarbazepine acetate for improved oral bioavailability. Mater Sci Eng 2016;C:826-34.

112. Yıldız S, Aytekin E, Yavuz B, Bozdag Pehlivan S, Unlu N. Formulation studies for mirtazapine orally disintegrating tablets. Drug Dev Ind Pharm 2016;42:1008-17.

113. Chen Y, Feng T, Li Y, Du B, Weng W. Formulation and evaluation of a montelukast sodium orally disintegrating tablet with a similar dissolution profile as the marketed product. Pharm Dev Tech 2017;22:168-72.

114. El Maghraby GM, Elsergany RN. Fast disintegrating tablets of nisoldipine for intra-oral administration. Pharm Dev Tech 2014;19:641-50.

115. Cantor SL, Khan MA, Gupta A. Development and optimization of taste-masked orally disintegrating tablets (ODTs) of clindamycin hydrochloride. Drug Dev Ind Pharm 2015;41:1156-64. 